DOI: $10.2478 / \mathrm{v} 10190-010-0004-4$

\title{
RESPONSES OF ANTARCTIC TUNDRA ECOSYSTEM TO CLIMATE CHANGE AND HUMAN ACTIVITY
}

\author{
MARIA OLECH \\ Institute of Botany, Jagiellonian University, Kopernika 27, 31-501 Cracow, Poland, \\ Department of Antarctic Biology, Polish Academy of Sciences, \\ Ustrzycka 10/12, 02-141 Warsaw, Poland \\ e-mail: maria.olech@uj.edu.pl
}

\begin{abstract}
Over the last couple of years the Antarctic Peninsula region has been one of the fastest warming regions on the Earth. Rapidly proceeding deglaciation uncovers new areas for colonisation and formation of Antarctic tundra communities. The most evident dynamics, i.e. changes in both biodiversity and structure of tundra communities, are observed in the forefields of retreating glaciers. This paper presents examples of changes in biodiversity and in the direction and rate of succession changes taking place due to climate warming compounded by synanthropization in the maritime Antarctic.
\end{abstract}

KEY WORDS: Antarctic, climate change, colonisation, tundra ecosystem, biodiversity, alien species.

\section{INTRODUCTION}

Development of vegetation in the Antarctic is limited to ice-free surfaces of the land, which account for only a few percent $(2-5 \%)$ of the total area. The Antarctic tundra ecosystem is mainly made up of cryptogams, i.e. lichens, bryophytes, algae and fungi, while at the same time it is extremely deficient in vascular plants, of which only two species are found: a grass Deschampsia antarctica Desv. (Poaceae) and Colobanthus quitensis (Kunth). Bartl. (Caryophyllaceae). Occurrence of both species is limited to the climatically favourable sites in the maritime Antarctic (Olech 2002).

The maritime Antarctic comprises the western coastal region of the Antarctic Peninsula to about $72^{\circ} \mathrm{S}$, South Shetland, South Orkney and South Sandwich archipelagos, and the isolated island of Bouvetøya (Lewis Smith 1996). 
The climate changes, which occur more intensely and rapidly in the polar regions, have a significant impact on terrestrial ecosystems. The high vulnerability of the Antarctic tundra results from low biodiversity, as well as a small range of its variability even under small climate fluctuations (Lewis Smith 1990). Therefore, special attention should be paid to the potential responses of these vulnerable ecosystems to the recent climate changes. Particularly profound changes are observed in the areas where rapid recession of glaciers takes place. Vegetation dynamics are most evident in the forefields of glaciers.

Maritime Antarctic, especially the Antarctic Peninsula region, is facing evident regional warming of the climate (King 1994; King, Harangozo 1998, Vaughan et al. 2003; Turner et al. 2005). It is particularly observable in the changes in the cover of glaciers, since the reduction in both the surface area and thickness of glaciers has been proceeding more and more rapidly. The retreat of glaciers shows a constant tendency in this area (Kejna et al. 1998; Battke et al. 2001; Birkenmajer 2002; Braun, Gossmann 2002; Angiel, Pudełko 2008). Deglaciation is continuously uncovering new areas from under the ice. This provides a unique opportunity to carry out research on biological colonisation and formation of simple ecological systems, such as tundra ecosystems in the glacier forefields and on young frontal, and lateral moraines. According to the latest research (Olech 2008a, 2008b; Olech, Massalski 2001), these processes have recently greatly accelerated due to rapid climate changes. Significant quantity and quality changes are observed in the structure of tundra communities. Besides the natural factors having an impact on colonisation, anthropogenic ones have been recently identified as well.

In view of the ongoing changes, multi-annual monitoring research is being carried out in the areas subject to deglaciation, aiming to record the dynamic processes occurring in the newly created ecosystems. The project covers long-term study of vegetation dynamics in the forefields of glaciers and on moraines of different ages, and of how the local climate warming influences these dynamics. Another objective is to observe the response of the terrestrial biota and Antarctic tundra ecosystem to climate warming factors in order to derive biotic indices that could serve as precise and universal bio-indicators sensitive to factors critical to the terrestrial ecosystems, and be used in investigation of future climate changes.

Attention has already been paid to the problems of the climate change impact on different elements of the Antarctic terrestrial ecosystems. However, this relates to selected taxonomic groups, e.g. vascular plants (Fowbert, Lewis Smith 1994; Lewis Smith 1994, 2001, 2003; Grobe et al. 1997), bryophytes and microbiota (Wynn-Willson 1996; Lewis Smith 1993, 2001) and invertebrate (Davies, Melbourne 1999). What is lacking is a comprehensive phytosociological analysis to address the essence of the issue.

This paper discusses the results of an experiment which consisted in monitoring research that covered all taxonomic groups contributing to the formation of the Antarctic tundra, and studying the impact of climate changes on the tundra ecosystem. 


\section{STUDY AREA}

Detailed studies of colonisation and dynamics of tundra communities are carried out on the solid surfaces of the moraines and glacier forefields being successively exposed within the region of the Antarctic Special Protected Area (ASPA) No. 128 (former SSSI No. 8) - Figure 1. The ASPA No. 128 is located on the west coast of the Admiralty Bay, King George Island, South Shetlands, maritime Antarctic. Within this area long-term studies are carried out in the forefields of the following: Ecology Glacier, Sphinx Glacier, Baranowski Glacier and Windy Glacier (Fig. 2).

Regression of the glaciers within the ASPANo. 128 area in the years 1979-2007 was the subject of research carried out by P. Angiel and R. Pudełko (Pudełko 2003; Angiel, Pudełko 2008). Climate warming on King George Island resulted in a change in the balance of the ice field called Warsaw Icefield, which feeds the glaciers in the ASPA No. 128 (Angiel, Pudełko 2008). This translates into changes in the range limits of glaciers in this area. In the years 1979-2007, the tongues of individual glaciers retreated by 200-900 metres (Pudełko 2003). As a consequence of the deglaciation process, large areas were uncovered in the forefields of the glaciers. These areas were covered by monitoring research which focused primarily on colonisation and biological succession. Since the ASPANo. 128 is located in the vicinity of the H. Arctowski Polish Antarctic Station and is exposed to the influences of human activity (the all-year-round research station, scientific penetrations, tourism), analogous research is carried out for comparison in the ASPA No. 151 (former SSSI No 34). The ASPA No. 151 is located on the west coast of the neighbouring King George Bay (Fig. 1). This area is almost devoid of anthropogenic influences since neither research stations are located there nor tourist excursions reach that far. Increased deglaciation is observed in this area as well, and comparative studies are being carried out in the forefield of the White Eagle Glacier. Between 1998 and 2009 , the ice wall of the White Eagle Glacier shifted by approx. 500 metres.

\section{COLONISATION AND SUCCESSION RESEARCH}

Long-term studies were carried out in the years 1991-2009. In the forefields of glaciers and on moraines of different ages transects were mapped, running from the ice walls of the retreating glaciers to the oldest contemporary moraines. Phytosociological research was carried out along the transects using the Braun-Blanquet method. Phytosociological releves were taken of $1 \times 1$ meter areas. The research included algae, fungi, lichens (lichenized fungi), bryophytes and vascular plants. At several points along each transect samples of soil were taken in order to investigate the physico-chemical properties of the substrate. In the forefields of the glaciers whose ice walls had been the first to retreat (Ecology Glacier, Sphinx Glacier), research carried out on the solid surfaces was repeated after several years. Analysis 
included floristic and phytosociological data, both archival and contemporary. Lists were compiled of the plant and fungi species recorded over two research periods, taking into account the frequency of their occurrence and the rate of coverage in patches. The current phytosociological releves, as compared with the archival data (both series were taken according to the Braun-Blanquet method), were used to determine the directions and rates of the changes taking place in the tundra communities.

\section{CHANGE IN BIODIVERSITY}

In the forefields under research, records were taken of groups of taxa declining (retreating from their occupied habitats) or clearly limiting their area of occurrence. These included lichens (lichenized fungi) such as the vanishing species Polyblastia gothica Th. Fr. and Thelocarpon cyaneum Olech \& Alstrup (lichenicolous fungi). Both species prefer significantly water-logged areas and are most frequently found at the base of long-lasting, mainly perennial snow patches lingering on mountain sides with long-stagnant water. Octospora arctowski Olech \& Mleczko, an Ascomycota fungus, may also be considered a vanishing species. The taxa modifying their range of occurrence are lichens: Protopannaria austro-orcadensis (Øvstedal) Jørg., Leptogium puberulum Hue and Placopsis contortuplicata I.M.Lamb. These species are associated with a very wet substrate. Examples of taxa decreasing their area of occurrence from among bryophyte species include the hydrophilous Warnstorfia sarmentosa (Wahlenb.) Hedenäs and W. fontinaliopsis (Müll. Hal.) Ochyra, both found in wet and often flushed habitats, forming spongy carpets in well drained swamps, and along the margins on melt runnels or lakes and ponds, as well as Syntrichia filaris (Müll. Hal.) R.H. Zander and Brachythecium austrosalebrosum (Müll. Hal.) Kindb., frequently occurring together with them. A liverwort Anthelia juratzkiana Limpr., which prefers prolonged snow covers, also decreases its area of occurrence.

Of the species which extend their area of occurrence, it is worthwhile to mention vascular plants Deschampsia antarctica and Colobanthus quitensis, as well as lichens Psoroma cinnamomeum Malme and Tephromela spp.

In individual forefields several new species were recorded, having appeared after several years during the second period of the transect-based research, for example Carbonea assentiens (Nyl.) Hertel, Placopsis antarctica D.J. Galloway, Lewis-Smith \& Quilhot in Sphinx Hill forefield. The accelerated rate of colonisation which has recently been observed in the forefields of glaciers (Olech, Massalski 2001) allows pioneer species to increase their share in these processes. Such species include, along with Deschampsia antarctica and Colobanthus quitensis, also Bryum pseudotriquetrum (Hedw.) P. Gaertn., B. argenteum Hedw. and Ceratodon purpureus (Hedw.) Brid. This also applies to the rock-inhabiting lichens such 
as: Caloplaca johnstonii (C.W.Dodge) Søchting et Olech, C. sublobulata (Nyl.) Zahlbr., Lecanora semipallida H. Magn., Candelariella aurella (Hoffm.) Zahlbr., Bacidia chrysocolla Olech, Czarnota et Llop etc. An increased share of epibryophytic lichens is observed as well Psoroma hypnorum (Vahl.) Grey, Rinodina olivaceobrunnea C.W. Dodge \& G.E. Baker and others.

The species which have colonised new areas of the Antarctic and increase their area of occurrence also include a species new to the region, namely a vascular plant Poa aпnиa L.

\section{CHANGE IN THE COMPOSITION OF TUNDRA COMMUNITIES}

Comparative studies carried out in the forefields of glaciers demonstrated significant changes in the structure of tundra communities. Moreover, certain communities were found to have disappeared, such as the community with Octospora arctowski and Henediella antarctica (Ångstr.) Ochyra, or several hygrophytic bryophyte communities. These communities of Warnstorfia spp. and Sanionia uncinata (Hedw.) Loeske develop in situations with a permanent supply of standing water. Their areas of occurrence are occupied by the community dominated by $D e-$ schampsia antarctica, or the community Deschampsia antarctica and Colobanthus quitensis. The transformation of a number of communities from wet and mossy ones to Deschampsia antarctica monocultures indicate the succession of the Antarctic tundra communities towards grassification. The observed dynamic tendencies indicate a change in the habitat conditions which results mainly from the local climate warming. This primarily concerns the dramatic decrease in the substrate humidity. Retreating glaciers and disappearance of perennial and seasonal snow patches result in the water inflow to the substrate being cut off.

Availability of liquid water appears to be more important than temperature to biological activity in the Antarctic terrestrial habitats (Sømme 1995; Block 1996; Convey and Lewis Smith 2006).

Consideration should also be given to the phenomena observed over the last years, consisting in overgrowing of peat bogs by the grass Deschampsia antarctica; such newly created "grass plots" attract large groups of pinnipeds, such as Antarctic fur seals (Arctocephalus gazella) or elephant seals (Mirounga leonina), which move here from coastal beaches. As a consequence the substrate gets strongly fertilized and trampled, which leads to further modifications of vegetation in these sites.

\section{HUMAN IMPACT ON THE CHANGES IN THE TUNDRA ECOSYSTEM}

One of the factors determining the specific character of the Antarctic ecosystems is the isolation of this area, which is responsible for its extreme deficiency in 
species. However, due to intensification of human activity, increased tourist traffic and scientific logistics, humans have discontinued the isolation of the Antarctic, and become a new vector for the transfer of propagules and opened up routes of introduction for alien species (Lee et Chown 2009). This has coincided with sudden changes in the environment, primarily the rapid warming of the maritime Antarctic, which is favourable to the settlement of alien invasive species (Frenot et al. 2005).

The research on the vegetation dynamics in the forefield of the Ecology Glacier included monitoring of colonisation of the forefield by the grass Poa annua L. This is the first ever report from the Antarctic on the share of an alien species in the primary succession of the areas recently uncovered from under the ice. Since 1996 Poa annua has been monitored on King George Island where it is found within the area of the H. Arctowski Polish Antarctic Station (Olech 1996, 1998, 2003). The invasion success of Poa annua and the establishment of a new range of its occurrence in the Antarctic owes to humans, who have become the vector for the propagule transfer. Genetic research (Chwedorzewska 2008) indicated that this plant has been brought to the area several times and from different sources of introduction. Having established at the Antarctic Station, where it settled in anthropogenic habitats, it was subsequently transferred by the wind and started colonising the surfaces uncovered from under the ice in the glacier forefield, becoming part of the natural tundra communities. Warming of the climate and synanthropization contributed to the colonisation success of this species within the area of the Antarctic.

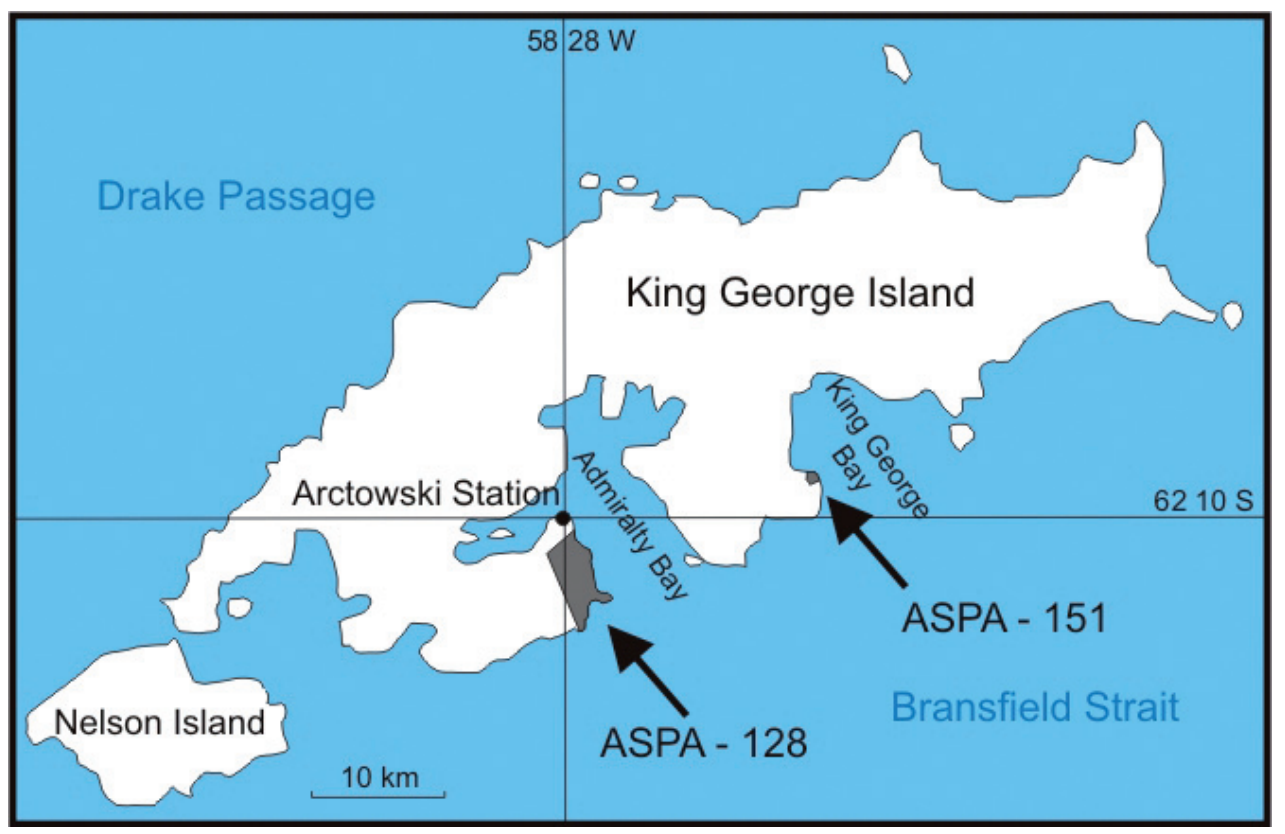

Figure 1. King George Island with location of ASPA No. 128 and ASPA No. 151 


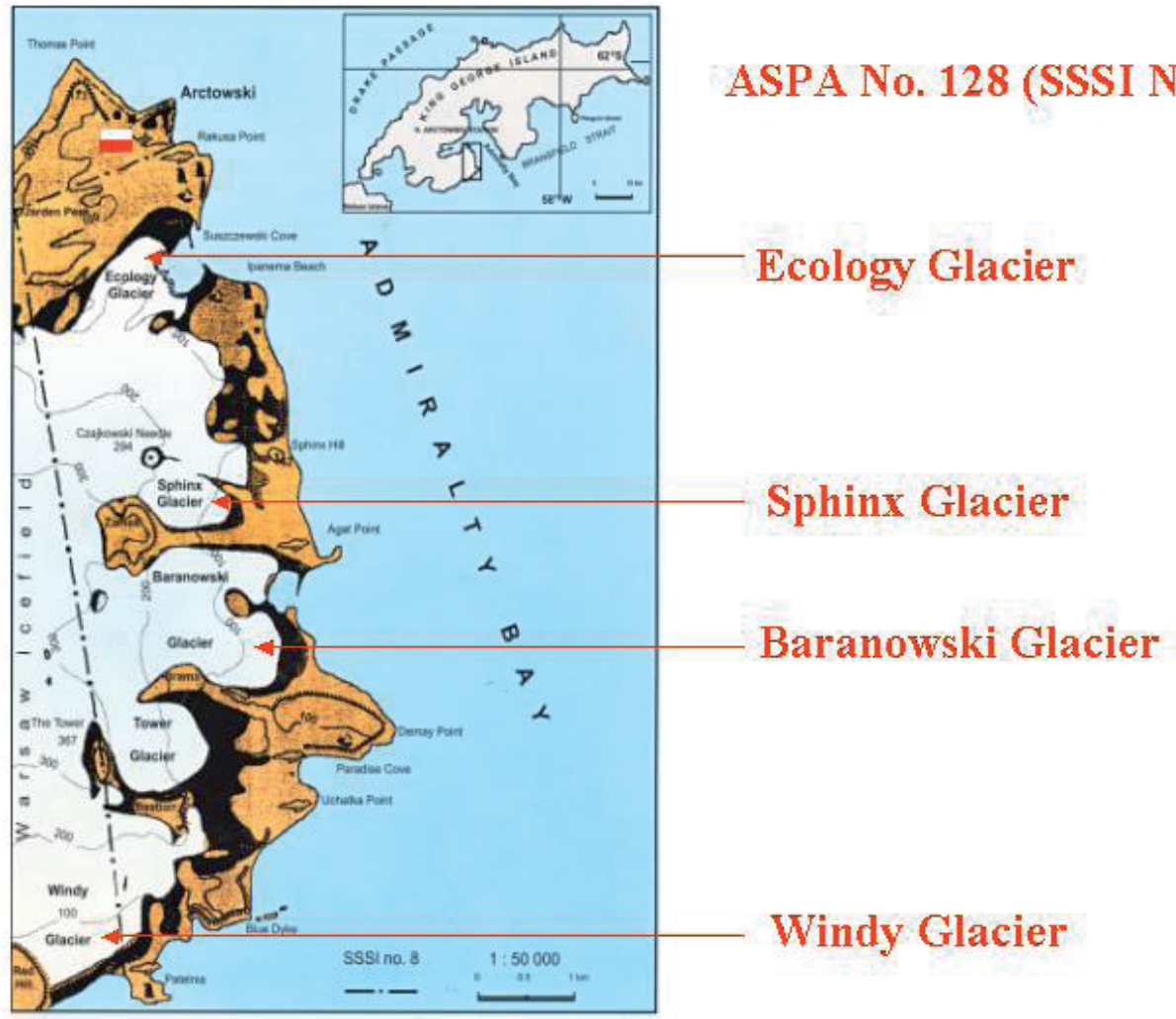

Figure 2. Location of the glacier forefields in the area of ASPA No. 128

\section{ACNOWLEDGMENTS}

This research was supported by grant IPY/27/2007.

\section{REFERENCES}

Angiel P., Pudełko R., 2008, Regresja lodowców w latach 1997-2007 na terenie ASPA-128 (Antarctic Special Protected Area 128), Wyspa króla Jerzego, Szetlandy Poludniowe, (Regression of the glaciers within the ASPA No. 128 area in the years 1979-2007), The 32 nd International Polar Symposium, Wrocław 23-24 V 2008, 13.

Battke Z., Marsz A.A., Pudełko R., 2001, Procesy deglacjacji na obszarze SSSI No. 8 I ich uwarunkowania klimatyczne oraz hydrobiologiczne (Zatoka Admiralicji, Wyspa Króla Jerzego, Szetlandy Poludniowe, (The processes of deglaciation in the region of SSSI 
No. 8 and their climatic and hydrobiological conditions), Problemy Klimatologii Polarnej, 11, 121-135.

Birkenmajer K., 2002, Retreat of Ecology Glacier, Admiralty Bay, King George Island (South Shetland Islands, West Antarctica) 1956-2001, Bulletin Polish Academy of Sciences: Earth Sciences, 50, 5-19.

Block W., 1996, Cold or drought - the lesser of two evils for terrestrial arthropods?, European Journal of Entomology, 93, 325-339.

Braun M., Gossmann H., 2002, Glacial Changes in the Areas of Admiralty Bay and Potter Cove, King George Island, Maritime Antarctica, [in:] Beyer L. and Bölter M. (eds), Geoecology of Antarctic Ice-Free Coastal Landscapes, Springer-Verlag Berlin Heidelberg, Ecological Studies, 154, 75-89.

Convey P., 2001, Terrestrial ecosystem response to climate changes in the Antarctic, [in:] "Fingerprints" of Climate Change-Adapted Behaviour and Shifting Species Ranges, Walther G.-R., Burga C.A. and Edwards P.J. (eds), Kluwer, New York, 17-42.

Convey P., Lewis Smith R.I., 2006, Responses of terrestrial Antarctic ecosystems to climate change, Plant Ecology, 18, 1-10.

Chwedorzewska K.J., 2008, Poa annua L. in Antarctic: searching for the resource of introduction, Polar Biology, 31, 263-268.

Davies K.F., Melbourne B.A., 1999, Statistical models on invertebrate distribution on Macquarie I.: a tool to assess climate change and local human impacts, Polar Biology, 21, 103-121.

Fowbert J.A., Lewis Smith R.I., 1994, Rapid population increases in native vascular plants in the Argentine Islands, Antarctic Peninsula, Arct. Alpine Res., 26, 290-296.

Frenot Y., Chown S.L., Whinam J., Selkirk P.M., Convey P., Skotnicki M., Bergstrom D.M., 2005, Biological invasions in the Antarctic: extent, impacts and implications, Biological Reviews, 80, 45-72.

Grobe C.W., Ruhland C.T. and Day T.A., 1997, A new population of Colobanthus quitensis near Arthur Harbor, Antarctica: correlating recruitment with warmer summer temperatures, Arct. Alpine Res., 29, 217-221.

Kejna M., 1999, Air temperature on King George Island, South Shetland Islands, Antarctica, Polish Polar Research, 20, 183-201.

Kejna M., Láska K., Caputa Z., 1998, Recession of Ecology Glacier (King George Island) in the period 1961-1996, Polish Polar Studies 25 ${ }^{\text {th }}$ International Symposium, Warszawa, 1998, Institute of Geophysics of the Polish Academy of Sciences, Warszawa, 121128.

King J.C., 1994, Recent climate variability in the vicinity of the Antarctic Peninsula, International Journal of Climatology, 14, 357-369.

King J.C., Harangozo S.A., 1998, Climate change in the western Antarctic Peninsula since 1945: observations and possible causes, Annals of Glaciology, 27, 571-575.

Lee J.E., Chown S.L., 2009, Quantifying the propagule load associated with the construction of an Antarctic research station, Antarctic Science, 21, 471-475.

Lewis Smith R.I., 1990, Signy Island as a paradigm of biological and environmental change in Antarctic terrestrial ecosystems, [in:] Kerry K.R., Hempel G. (eds), Antarctic Ecosystems, Ecological Change and Conservation., Springer-Verlag, Berlin, 30-48. 
Lewis Smith R.I., 1993, The role of bryophyte propagule banks in primary succession: case study of an Antarctic fellfield soil, [in:] Milesand J. and Walton D.W.H. (eds), Primary succession on land, Blackwell Scientific Publishing, Oxford, 55-77.

Lewis Smith R.I., 1994, Vascular plants as indicators of climate change in the Antarctic, Oecologia, 99, 322-328.

Lewis Smith R.I., 1996, Introduced plants in Antarctica; potential impacts and conservation issues, Biological Conservation, 76, 135-146.

Lewis Smith R.I., 2001, Plant colonization response to climate change in the Antarctic, Folia Facultatis Scientiarium Naturalium Universitatis masarykianae brunensis, Geographia, 25, 19-33.

Lewis Smith R.I., 2003, The enigma of Colobanthus quitensis and Deschampsia antarctica in Antarctica, [in:] Huiskes A.H.L., Gieskes W.W.C., Rozema J., Schorno R.M.L., van der Vies S.M., Wolff W.J. (eds), Antarctic biology in a global context, Backhuys Publishers, Leiden, 234-239.

Olech M., 1996, Human impact on terrestrial ecosystems in west Antarctica, Proceedings of the NIPR Symposium on Polar Biology, 9, 299-306.

Olech M., 1998, Synantropization of the flora of Antarctica: an issue, [in:] Faliński J.B., Adamowski W., Jackowiak B. (eds), Synantropization of plant cover in new Polish research, Phytocoenosis 10, Supplementum Cartographiae Geobotanicae, 9, 269-273.

Olech M., 2002, Plant Communities on King George Island, [in:] Beyer L., Bölter M. (eds), Geoecology of Antarctic Ice-Free Coastal Landscapes, Ecological Studies, Vol. 154, Springer -Verlag Berlin, Heidelberg, 215-231.

Olech M., 2003, Expansion of alien vascular plant Poa annua L. in the vicinity of the Henryk Arctowski Station - a consequence of climate change?, [in:] Olech M. (ed.), The functioning of polar ecosystems as viewed against global environmental changes, XXIX International Polar Symposium, 89-90.

Olech M., 2008a, Kolonizacja I sukcesja roślinności na przedpolach lodowców w Antarktyce Zachodniej, The $32^{\text {nd }}$ International Polar Symposium, $4^{\text {th }}$ International Polar Year, Wrocław, 23-24 May 2008, 59-60.

Olech M., 2008b, Plant colonization and development of communities on the deglaciated areas of the maritime Antarctica, Polar Research - Arctic and Antarctic perspectives in the International Polar Year, SCAR/IASC IPY Open Science Conference, St. Petersburg, Russia, 8-11 July 2008, Abstract Volume, 215 pp.

Olech M., Massalski A., 2001, Plant colonization and community development on the Sphinx Glacier forefield, Folia Facultatis Scientiarium Naturalium Universitatis Masarykianae Brunensis, Geographia, 25, 111-119.

Pudełko R., 2003, Topographic map of the SSSI No 8, King George Island, West Antarctica, Polish Polar Research, 24, 53-60.

Sømme L., 1995, Invertebrates in Hot and Cold Arid Environments, Springer-Verlag, Berlin.

Turner J., Colwell S.R., Marshall G.J., Lachlan-Cope T.A., Carleton A.M., Jones P.D., Lagun V., Reid P.A., Iagovkina S., 2005, Antarctic climate change during the last 50 years, International Journal of Climatology, 25, 279-294. 
Vaughan D.G., Marshall G.J., Connolley W.M., Parkinson C., Mulvaney R., Hodgson D.A., King J.C., Pudsey C.J., Turner J., 2003, Recent rapid regional climate warming on the Antarctic Peninsula, Climate Change, 60, 243-274.

Wynn-Williams D.D. 1996, Response of pioneer soil microalgal colonists to environmental change in Antarctica, Microbial Ecology, 31, 177-188. 